\title{
Impact of Climate Change on Seasonal Rainfall Patterns over Bale Highlands, Southeastern Ethiopia
}

\author{
Wogayehu Legese Jima ${ }^{1,2,{ }^{*} \text {, Deriba Korecha }}{ }^{3}$, Kasahun Ture ${ }^{4}$ \\ ${ }^{1}$ Department of Space and Its Application, Addis Ababa University, Ethiopian Space Science and Technology Institute, Addis Ababa, \\ Ethiopia \\ ${ }^{2}$ Department of Environmental Science, Madda Walabu University, Natural and Computational Collage, Bale Robe, Ethiopia \\ ${ }^{3}$ Department of Science, Institution: Famine Early Warning Systems Network (FEWSNET), Addis Ababa, Ethiopia \\ ${ }^{4}$ Department of Environmental Science, Addis Ababa University, Center for Environmental Science, Addis Ababa, Ethiopia
}

Email address:

wogmet@gmail.com (W. L. Jima),dnwog2000@yahoo.com (W. L. Jima), diriba.korecha@gmail.com (D. Korecha), tkassa2010@gmail.com (K. Ture)

${ }^{*}$ Corresponding author

\section{To cite this article:}

Wogayehu Legese Jima, Deriba Korecha, Kasahun Ture. Impact of Climate Change on Seasonal Rainfall Patterns over Bale Highlands, Southeastern Ethiopia. International Journal of Environmental Chemistry. Vol. 3, No. 2, 2019, pp. 84-91. doi: 10.11648/j.ijec.20190302.15

Received: September 6, 2019; Accepted: Octorber 24, 2019; Published: December 31, 2019

\begin{abstract}
The objective of this study was evaluates the impact of climate change on seasonal rainfall patterns over Bale Highlands by using climate data from National Meteorology Agency and downscaling Coordinated Regional Climate Downscaling Experiment (Cordex) output data from cordex Africa. In order to estimate the climate change signal scenarios of rainfall and temperature were developed for periods of 30 years (2011 to 2100). The outputs GCM model for the RCP4.5 and RCP8.5 emission scenarios were used to produce the future scenarios. Instat V3.7 software was governed for this study. The sample size for this study was 768 respondents randomly selected. Results of R $2=0.58$ for temperature over study area which shows that there is a good correlation between downscaled and observed data. The study shows that there is an overall increasing trend in seasonal maximum and minimum temperatures and decreasing of seasonal rainfall from the base period. The onset, cessation and Length of Growing Periods in both Belg and Kiremt season shifts from the base years. Observational data, GCM date and farmer's perception showed similar result and there is a shift of seasons over Bale highlands form 2 days to dekade. During Kiremt season there was decreasing of LGP from 109 to 101. Similarly, the LGP of Belg was reduced from 84 days to 48 days at the end of $21^{\text {st }}$ century. The onset of Belg season at the end of 21 st century will shifts to May. The anticipated shift of Kiremt season will merging to Bega (dry season) with this the author recommended the local farmers or any concerned body uses this information which is significant amount of rainfall require appropriate acclimatization strategies to minimize risks, increase crop productivity, and avert food insecurity of the area.
\end{abstract}

Keywords: Bale Highlands, Climate Change, Rainfall Pattern, Seasonal, Southeast, Ethiopia

\section{Introduction}

Climate change signal is the impacts of climate change due to the high concentration of greenhouse gases in the atmosphere. There are different types of climate change signals or indicators, i.e. temperatures are rising, snow are melting and rainfall patterns are shifting, and more extreme climate events like heavy rainstorms and record-high temperatures (Heat waves) are already affecting society and ecosystems [1]. Different studies have conducted to assess the impact of climate change on hydrology in different parts of the world [2-5]. The projected increment in rainfall over East Africa is steady across the ensemble of models, with 18 of the 21 models projecting an increase in the core of this region, east of the Great Lakes [6]. Other results based on analysis of three precipitation time series indicate substantial dryness across most of eastern Africa during the Belg rains. For instance; Tanzania, Rwanda, Burundi, Kenya and Ethiopia have all experienced rainfall deficits ranging from 50 to $150 \mathrm{~mm}$ per season [7]. Funk's further stated that 
"multiple sources of evidence converge on a post-1997 tendency towards lower rainfall, especially during the Belg (March-May) season. This finding appears to hold for many parts of eastern Africa." As the major part of the African continent has a tropical or subtropical climate, the seasonal migration of the tropical rain belts is one of the main phenomena. Small shifts in the position of these rain belts may result in large local changes in rainfall $[6,8]$ Has shown that the change in rainfall over the Blue Nile basin would be between +2 and $+11 \%$ for 2030 , while rainfall over the White Nile basin would increase between 1 and $10 \%$ for the same year. Rainfall in Ethiopia is characterized by high spatial and temporal variability as a result of the topographic variation and geographical location. Thus, rainfall activity on locations with the same altitude can differ depending on whether they are found over the windward or on the leeward side. As a result, one can observe great difference in the rainfall between the different parts of Bale Highlands which are on the same homogeneous types of rainfall [9]. Ethiopia is characterized by three distinct seasons. These are locally known as Bega (October to January), Belg (February to May) and Kiremt (June to September). The rainfall pattern is also named according to their rainfall distribution [10]. Therefore, the objective of the this study was to examine the impacts of climate change to shift start of the season or onset, end of season or cessation and LGP of seasons during both small rainy (Belg) season and main rainy (Kiremt) season over Bale Highlands. There are limited attempt that made to employ appropriate scientific explorations on the impact of climate change on seasonal onset, cessation and length of growing period over Bale Highlands in particular. The present study is therefore; supposed to show the shift of start date, end date and length of growing periods of the seasons due to climate change over Bale Highlands till 2100 or at the end of 21 st century.

\subsection{Characteristics of Rainfall and Its Distribution Over Bale Highland}

There are two rainy periods over study area locally known as Kiremt (June to September) which is long rainy period and Belg (February to May) which is short rainy periods. 600$1000 \mathrm{~mm}$ of rain falls annually in the lower altitude areas and $1000-1400 \mathrm{~mm}$ in the higher altitudes [11-14]. Mean annual rainfall distribution increases from east and southeast to west, north and southwest of the highlands. Overall, the mean annual rainfall totals range from 844.6 to $1321.7 \mathrm{~mm}$ over the eastern and western parts of the highlands, respectively.

\subsection{Onset of Belg and Kiremt Seasons}

Onset of Belg season is difficult to define because of highly erratic characteristics. In Bale highlands Belg onset is differ from place to place. As Bale highland is partly Belgrain-benefiting areas, the Belg season is defined as the time when the first wet spell of at least three days total rainfall amount of $20 \mathrm{~mm}$ or more occurs in February, provided there will not be continuous nine or more dry spell or dry days in the subsequent 30 days of the area [15]. According to [16] over Bale Highlands the onset of Kiremt start's from Jun25 th. The Onset of Kiremt season starts from the $1^{\text {st }}$ month of the season June and defined the time when the first wet-spell of June month occurs at least three days total rainfall amount of $20 \mathrm{~mm}$ or more, provided there were no continuous nine or more dry spell or day days in the subsequent 30 days.

\subsection{Cessations of Belg and Kiremt Seasons Over Bale Highland}

The end of rainy season is obtained when a dekadal rainfall amount is less than half of the corresponding reference evapotranspiration (ETo) at the end of rainy season [16]. In the previous studies there is no exact cessation of Belg season for Bale highlands due to less Meteorological stations data. According to [16] over Bale highland the Cessations of Kiremt season is from Oct-15 to Oct-26 from eastern to western of the highland, respectively.

\section{Materials and Methods}

\subsection{Background of the Study Area}

Bale Highlands is located between $6.45 \mathrm{~N}$ to $7.45 \mathrm{~N}$ and 39.47E to $40.77 \mathrm{E}$ in the southern parts of Oromia National Regional State of Ethiopia. The total study area of the Highlands is covers $13,291 \mathrm{~km}^{2}$, which is contain 9 Districts of Bale Zone, namely; Agarfa, Berebere, Dinsho, Gasera, Ginir, Goba, Gololcha, Goro and Sinana. The elevation of Bale Highlands ranges from 1500 to 3500 meter above sea level [17]. The study area is enclosed in the south by Mena, in the west by West Arsi Zone, in the north by Arsi Zone and in the east by Sewena district. The highest point in Bale Highland is Mount Tuludimtu (4377mand Batu Mount (4307 $\mathrm{m})$, Based on the topography Bale is divided into Dega (Highland), Waine Dega (mid lands), and Kola (low lands). In the study area, Barley and Wheat are highly produced [18]. Most of these districts are characterized by bimodal rainfall types. Various studies indicate that the study area is dense or populous because the region is highly fertile and suitable for agricultural activities [19]. The current study is mainly focused on the Highlands parts of Bale Zone [20].

\subsection{Data Used and Method of Analysis}

\section{Data Set}

\subsubsection{Observed Meteorological Data (Data Sources)}

All historical meteorological data were collected from Southern Oromia Meteorological Center of National Meteorological Agency (NMA) of Ethiopia. The data sets format is daily rainfall from 12 meteorological stations.

\subsubsection{General Circulation Models (Gcms) Data}

Model outputs of the two new RCP emission scenarios were downloaded from CORDEX Africa Group (http://www.csag.uct.ac.za). Those two new RCP scenarios are RCP4.5 and RCP8.5. The assumptions of Both RCP4.5 
and RCP8.5 for future were the released of greenhouse gas, pollutants, socio-economic change, technological change, energy, land use and other driving forces [21]. The CORDEX-GCM provides daily meteorological forcing for the period 1951-2100.

\subsection{Sampling and Sample Size Determination}

For this study the random sample method was used and total of 768 respondents were randomly selected. Simple random sampling (SRS) technique was used to select the study population for sample collection in the study area. Districts are located in the same rainfall homogeneity [9]. SRS technique is applied on household farmers or kebeles in each selected district. In order to determine the desired sample size there is no previous reports of population in the Bale Highland was considered as expected prevalence. The expected prevalence rate was $50 \%$ for the area within $95 \%$ confidence intervals $(\mathrm{CI})$ at $5 \%$ desired accuracy as stated by [26]. To develop the perception among local community about the climate change impacts, data was collated using structured questioners and for sample size

$$
n=\frac{\left(Z^{2} \times p \times q\right) d}{e}
$$

Where, $\mathrm{n}$ is Sample size determination and allocation proportion.

$\mathrm{Z}$ is Confidence of level 95\% $(\mathrm{Z}=1.96)$

$\mathrm{P}$ is Proportion $(\mathrm{p}=0.5)$

$\mathrm{q}=1-\mathrm{p}$

$\mathrm{d}$ is Design effect and use to composet the error or reduce the error $(d=1.5,2$ and 3 but for this study $d=2)$

$\mathrm{e}$ is Margin of error $(\mathrm{e}=0.5)$.

\subsection{Data Pre-processing}

Data were captured into Microsoft Excel 2010 spreadsheet following the days of year (DOY) entry format. In order to make the series amenable to further analyses, the missing values were patched using gridded data. The downloaded data also adjusted by using Microsoft Excel 2010 spreadsheet. The future time scales from the year 2011 to the end of $21^{\text {st }}$ Century were divided into three climate periods of 30 years and their respective changes were determined for onset, cessation and LGP of each season. The distributed questioners for respondent farmers' perception written in English language and then the data collector translate it in to the Afan-Oromo, the language of the community.

\subsection{Data Analysis}

Twelve selected stations were categorized as Central, Eastern, Western, Southern and Northern parts. The variability of seasonal rainfall was analyzed for its onset, end date, LGP. Statistical packages like the mean, standard deviation and coefficient of variation were determined and interpreted based on Australian Bureau of Meteorology rainfall index [22]. For this study determining the onset, end date and LGP was performed by adapting definition from
[23]. Accordingly, the day with accumulated rainfall of $20 \mathrm{~mm}$ over three consecutive days that were not followed by greater than 9 days of dry spell length within 30 days from planting day was said to be onset date. The end of the rainy season adopted in this case was defined as any day after the first of September/October/, when the soil water balance reaches zero [23]. In addition, a fixed average 3.5 to $5 \mathrm{~mm}$ of Evapo-transpiration per day, and $100 \mathrm{~mm} / \mathrm{meter}$ of the maximum soil water holding capacity of the area [24] were considered. Given the above definitions, Instat Statistical programme Version 3.37 [23] was used for analysis using January to December calendar. The LGP was determined by subtracting onset date from end date. In this paper, Excel, Arc GIS, Statistical software Instat version 3.7 were used for determining Onset, Cessation, Length of Growing Period (LGP).

\section{Result and Discussion}

\subsection{Onset, Cessation and Length of Growing Period of Kiremt and Belg Seasons (Onset) for Base Year (1986- 2005)}

\subsubsection{Start of Kiremt and Belg Seasons (Cessation) for Base Year (1986-2005)}

The small rainy season (Belg) starts or onset period over Bale Highlands in average was March $28^{\text {th }}$ day of the year (DOY, 88) [27]. The result presented in Table 5 revealed that, on an average, the small rainy season (Belg) starts on March $25^{\text {th }}$ day of the year (DOY, 85) that is agree with previous finding. Starts of the season begins March $26^{\text {th }}(\mathrm{DOY}, 86)$ for Central Bale Highland, March $28^{\text {th }}$ (DOY, 88) for Eastern Bale highland, March $22^{\text {nd }}$ (day DOY, 82), for Western Bale highland, March $29^{\text {th }}$ (DOY, 89) for Northern Bale Highland and March $22^{\text {nd }}$ (DOY, 82) for Southern Bale Highland. According to Korecha and Barnston [9], the start date of the Belg season does not vary significantly over Bale Highlands which stated that Bale Highlands possess one Homogeneous Rainfall Regime [27]. The Central, Eastern, Western, Northern and southern parts of Bale Highland experienced a Standard deviation of 18, 17, 19, 24, 20 days and Coefficient of Variation (CV) of $21 \%, 19 \%, 23 \%, 26 \%$ and $24 \%$, respectively (table 1). Overall, start of the season ranges between $22^{\text {nd }}$ to $29^{\text {th }}$ days of the years which indicate that start of the season does not vary significantly over bale highland, this result agrees with the finding by [9], which stated that Bale Highlands possess one Homogeneous Rainfall Regime. The average onset of the main growing season (Kiremt) which is consistent with the previous work of Segele and Lamb [26] was July $1^{\text {st }}$ over Bale Highland which is lies in the $1^{\text {st }}$ dekade of July [27]. In this study, on the average the main rainy season (Kiremt) starts on July $8^{\text {th }}$ (Day of the year (DOY, 190) (table 2). Starts of the season originates Jul $16^{\text {th }}$ day of the year (198 DOY), for Central Bale Highland, August $5^{\text {th }}(218$ DOY), for Eastern Bale Highland, Jul $7^{\text {th }}$ (189 DOY), for Western Bale Highland, June $26^{\text {th }}$ (Day of the year (178 DOY) for Northern Bale 
Highland and July $4^{\text {th }}$ (Day of the year (DOY, 186) for Southern Bale Highland accounts a Standard deviation of 27, 42, 21, 26, 20 days and CV (Coefficient of Variation) 12\%, $17 \%, 11 \%, 15 \%$ and $11 \%$, respectively. This finding is agree with Legese W. finding (Segele and Lamb [16, 27].

\subsubsection{End of Kiremt and Belg Seasons (Cessation) for Base Year (1986-2005)}

The mean value of end date of Belg (small rainy) season for Bale Highland was on June $17^{\text {th }}$ (DOY, 169) [27]. see table 2. The small rainy season terminated over Central, Eastern, Western, Northern and Southern parts of Bale Highlands on June $8^{\text {th }}$ (DOY, 160), June $10^{\text {th }}$ (DOY, 162), June $30^{\text {th }}\left(\right.$ DOY, 182), June $17^{\text {th }}$ (DOY, 169) and June $10^{\text {th }}$ (DOY, 162), respectively. The Central, Eastern, Western, Northern and Southern parts of Bale Highlands has a Standard deviation of $34,20,21,38,36$ days and CV (Coefficient of Variation) 21\%,12\%, 14\%, 22\% and 23\%, respectively (table 1). There is the highest variability of the mean cessation of Belg season occurs over Bale Highlands [27]. According to Segele and Lamb [16] over Bale highland the Cessations of Kiremt season is from Oct-15 to Oct-26. The mean value of end date of Kiremt (main rainy) season for Bale Highland was on October $26^{\text {th }}$ (Day of year (DOY, 300). The main rainy season terminate over Central, Eastern, Western, Northern and Southern parts of Bale Highlands in November $2^{\text {nd }}\left(\right.$ DOY, 307), November $4^{\text {th }}$ (DOY, 309), October $23^{\text {rd }}$ (DOY, 297), October $28^{\text {th }}$ (DOY, 302) and October $31^{\text {st }}$ (DOY, 305) experienced a Standard deviation of $17,24,20,17,21$ days and CV (Coefficient of Variation) $6 \%$,
$8 \%, 7 \%, 6 \%$ and $7 \%$, respectively (table 2 ). CV for the end date of Kiremt season over Bale Highlands shown as less variability of cessations under $\mathrm{CV}$ classification that stated by [25].

\subsubsection{Length of the Growing Period (LGP) for Base Year (1986-2005)}

The average value of length of growing period (LGP) for small rainy season over Bale Highlands was 73 days in previous study 30 years of rainfall data for periods of (1985 to 2014) [27]. In this study, the average value of length of growing period (LGP) for small rainy season over Bale Highlands was 84 days (table 5). The length of growing period for the small rainy season over the Central, Eastern, Western, Northern and Southern parts of Bale Highland was $74,74,69,80$ and 80 days, respectively. The length of growing periods for the small rainy season over Bale Highlands ranges between 69 and 80 days (table 1). The average value of length of growing period during main rainy season over Bale Highlands was 110 days stated by [27]. The current study was agree with previous finding Legese [27]. For this finding the average value of length of growing period during main rainy season over Bale Highlands was 110 days (table 5). The length of growing period for the main rainy season over the Central, Eastern, Western, Northern and Southern parts of Bale Highland was 109, 91, 108, 127 and 119 days, respectively. The length of growing period for main rainy season over Bale Highlands ranges between 91 and 127 days (Table 2).

Table 1. Onset, Cessation and LGP of Belg for base year (1986 to 2005) over Bale Highlands.

\begin{tabular}{|c|c|c|c|c|c|c|c|}
\hline Parts of Highland & FMAM_EOS & StDV & $\mathrm{CV}$ in $\%$ & FMAM_SOS & StDV & $\mathrm{CV}$ in $\%$ & LGP \\
\hline Central & $8^{\text {th }}$-June & 34 & 21 & $26^{\text {th }}-\mathrm{Mar}$ & 18 & 21 & 74 \\
\hline East & $10^{\text {th }}$-June & 20 & 12 & $28^{\text {th }}-\mathrm{Mar}$ & 17 & 19 & 74 \\
\hline West & $30^{\text {th }}-$ May & 21 & 14 & $22^{\text {nd- }}$ Mar & 19 & 23 & 69 \\
\hline North & $17^{\text {th }}$-June & 38 & 22 & $29^{\text {th }}-\mathrm{Mar}$ & 24 & 26 & 80 \\
\hline South & $10^{\text {th }}$-June & 36 & 23 & $22^{\text {nd }}-M a r$ & 20 & 24 & 80 \\
\hline
\end{tabular}

Table 2. Onset, Cessation and LGP of Kiremt for base year (1986 to 2005) over Bale Highlands.

\begin{tabular}{llllllll}
\hline Parts of Highland & JJAS_EOS & StDV & CV in \% & JJAS_SOS & StDV & CV in \% & LGP \\
\hline Central & $2^{\text {nd }}-$ Nov & 17 & 6 & $16^{\text {th }}-$ Jul & 27 & 12 & 109 \\
East & $4^{\text {th }}$-Nov & 24 & 8 & $5^{\text {th }}$ Aug & 42 & 17 \\
West & $23^{\text {rd }}-$ Oct & 20 & 7 & $7^{\text {th }}-J u l$ & 21 & 11 & 11 \\
North & $28^{\text {th }}-$ Oct & 17 & 6 & $26^{\text {th }}-$ Jun & 26 & 15 & 108 \\
South & $31^{\text {st }}-$ Oct & 21 & 7 & $4^{\text {th }}-J u l$ & 20 & 11 & 119 \\
\hline
\end{tabular}

The regularity onset and cessation over the study area is not clearly cited due to less meteorological station but the region consider as a Belg-growing areas and the onset and cessation period was in average $1^{\text {st }}$ dekade of March and $1^{\text {st }}$ dekade of June, respectively [15]. The mean onset and cessation in practicability and regularity within the region under kiremt season over Bale Highlands was July 1 st (DOY, 183) and October 28 (302), respectively over of Bale Highlands that represented only by Robe meteorological station. The LGP of kiremt over Bale highlands was 119 [16] Table $1 \&$ table 2 shown that there was a slight agreement the onset, cessation and LGP of season with the finding of segele and lamb over Bale Highlands.

\subsection{Farmer's Perception of Belg and Kiremt Seasons Onset}

Farmers perceive in a different way on the concept of season onset. The level of their understanding depends on their experience, education and location. In this study it was found that farmers have responded as a shifted onset on the perception they possess on seasonal onset for both Belg and Kiremt seasons that showed below. The onset of Belg season in the perspective of Farmer's later 1995 over Bale 
Highland was lies between $3^{\text {rd }}$ dekade of February and $3^{\text {rd }}$ dekade of March (figure 1). The farmers respond later 20 years (until 1995) showed in Figure 1 indicated that $25.8 \%$, $55.2 \%, 14.6 \%$ and $4.4 \%$ of the respondents onset of Belg season were $3^{\text {rd }}$ dekade of February, $1^{\text {st }}$ dekade of March $2^{\text {nd }}$ dekade of March and $3^{\text {rd }}$ dekade of March, respectively.

The farmers respond earlier 20 years (from 1995 to 2014) showed in (Figure 2) stated that $11.2 \%, 36.6 \%, 42.3 \%$ and $9.9 \%$ onset of Belg season was $1^{\text {st }}$ dekade of March, $2^{\text {nd }}$ dekade of March, $3^{\text {rd }}$ dekade of March and $1^{\text {st }}$ dekade of April, respectively. The kiremt season onset in the viewpoint of Farmer's later 1995 for 20 years over Bale Highland was lies between $2^{\text {nd }}$ dekade of July and $3^{\text {rd }}$ dekade of August. Figure 3 indicate that, $2^{\text {nd }}$ dekade of July, $3^{\text {rd }}$ dekade of July, $1^{\text {st }}$ dekade of August, $2^{\text {nd }}$ dekade of August and $3^{\text {rd }}$ dekade of August was $39.6 \%, 11.8 \%, 13.2 \%, 22.4 \%$ and $13 \%$, respectively. Starting 1995 for 20 years the onset of Kiremt season over Bale Highlands indicated in figure 4, starts from $3^{\text {rd }}$ dekade of July, $1^{\text {st }}$ dekade of August, $2^{\text {nd }}$ dekade of August, $3^{\text {rd }}$ dekade of August and $1^{\text {st }}$ dekade of September $0.8 \%$, $6.5 \%, 17.2 \%, 30.1 \%$ and $45.4 \%$ were the response of respondents, respectively. This results shows as the respondent's response of onset was match with the table 7 .

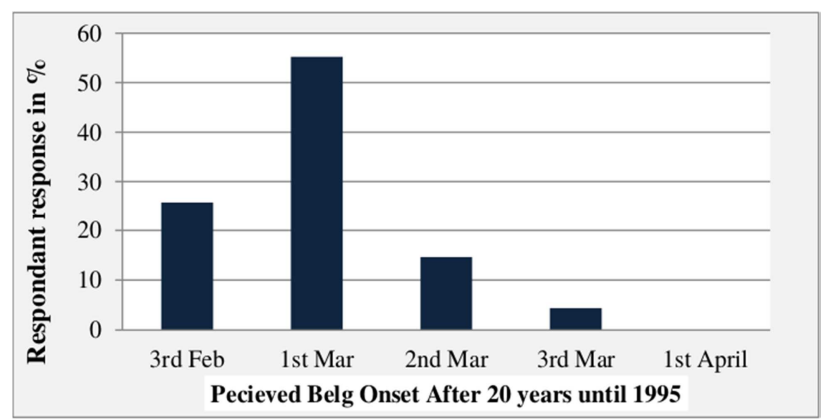

Figure 1. Farmer's Perception Belg season onset after 1995.

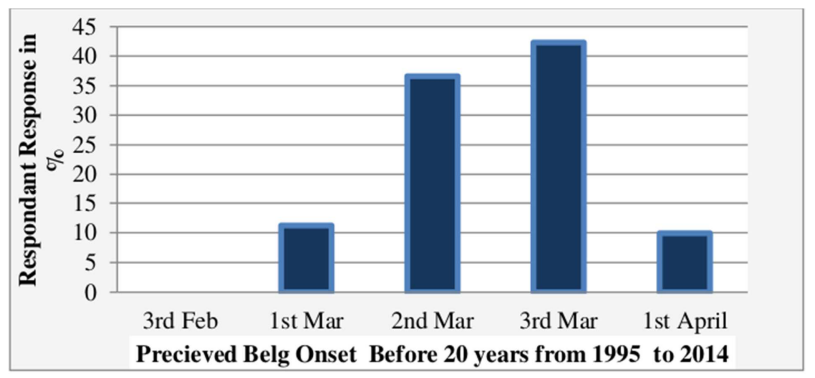

Figure 2. Perception of Farmer's on the onset of Belg season before 1995

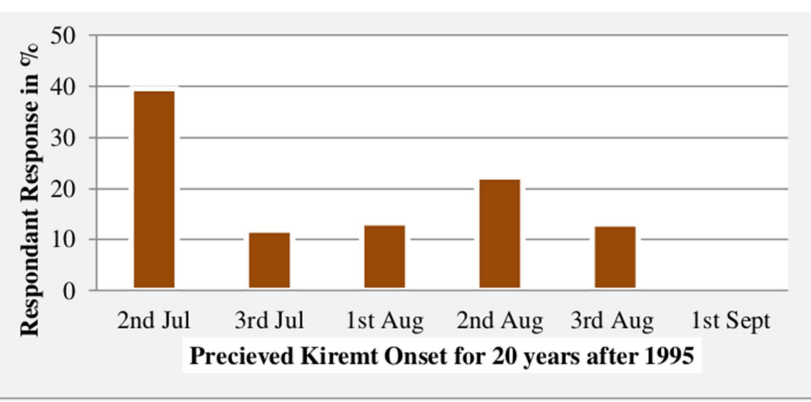

Figure 3. Farmer's perception Kiremt season onset after 1995.

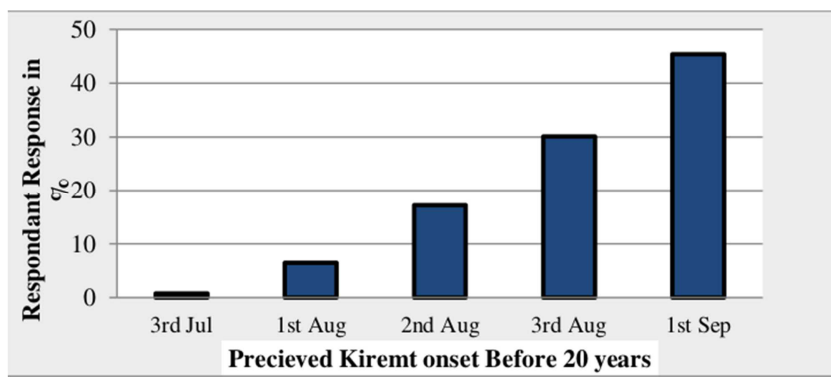

Figure 4. Farmer's perception Kiremt seasons onset before 1995.

\subsection{Seasonal Shifting and Farmer's Perception on Seasons Over Bale Highlands}

There is a link between seasonal rainfall pattern and farmer's perception for last 20years from 1995 to 2014 shown in the figure and table below.

Table 3. Onset, Cessation and LGP of Belg season from 1995 to 2014 over Bale Highlands.

\begin{tabular}{llll}
\hline Parts of Highland & FMAM_EOS & FMAM_SOS & LGP \\
\hline Central & $157\left(5^{\text {th }}-\right.$ Jun $)$ & $88\left(28^{\text {th }}-\right.$ Mar $)$ & 69 \\
East & $163\left(11^{\text {th }}-\right.$ Jun $)$ & $89\left(29^{\text {th }}-\right.$ Mar $)$ & 74 \\
West & $153\left(1^{\text {st }}-\right.$ Jun $)$ & $85\left(25^{\text {th }}-\right.$ Mar $)$ & 68 \\
North & $163\left(11^{\text {th }}-\right.$ Jun $)$ & $91\left(31^{\text {st }}-\right.$ Mar $)$ & 72 \\
South & $166\left(14^{\text {th }}-\right.$ Jun $)$ & $86\left(26^{\text {th }}-\right.$ Mar $)$ & 80 \\
\hline
\end{tabular}

The Belg season onset earlier 20 years (1995 to 2014) presented in table 6 was March $28^{\text {th }}$, March $29^{\text {th }}$, March $25^{\text {th }}$, March $31^{\text {st }}$ and March $26^{\text {th }}$ for Central, Eastern, Western, Northern and Southern parts of Bale Highlands, respectively. The end date of Belg season since 1995 to 2014 presented in table 6 was June $5^{\text {th }}$, June $11^{\text {th }}$, June $1^{\text {st }}$, June $11^{\text {th }}$ and June $14^{\text {th }}$ for Central, Eastern, Western, Northern and Southern parts of Bale Highlands, respectively. The Kiremt season onset from 1995 to 2014 cited in table 7 was July $17^{\text {th }}$, August $8^{\text {th }}$, July $9^{\text {th }}$, July $1^{\text {st }}$ and July $10^{\text {th }}$ for Central, Eastern, Western, Northern and Southern parts of Bale Highlands, respectively. The end date of Kiremt season from 1995-2014 presented in table 7 was November $7^{\text {th }}$, November $7^{\text {th }}$, November $1^{\text {st }}$, October $29^{\text {th }}$ and October $29^{\text {th }}$ for Central, Eastern, Western, Northern and Southern parts of Bale Highlands, respectively. The LGP of Belg season lies between 69 to 80 days over Bale Highlands. Similarly, LGP of Kiremt season lies between 91 to 120 days for base years.

Table 4. Onset, Cessation and LGP of Kiremt season from 1995 to 2014 over Bale Highlands.

\begin{tabular}{llll}
\hline Parts of Highland & JJAS_EOS & JJAS_SOS & LGP \\
\hline Central & $312\left(7^{\text {th }}-\right.$ Nov $)$ & $199\left(17^{\text {th }}-\right.$ Jul $)$ & 113 \\
East & $312\left(7^{\text {th }}-\right.$ Nov $)$ & $221\left(8^{\text {th }}-\right.$ Aug $)$ & 91 \\
West & $306\left(1^{\text {st }}-\right.$ Nov $)$ & $191\left(9^{\text {th }}-J u l\right)$ & 115 \\
North & $303\left(29^{\text {th }}-\right.$ Oct $)$ & $183\left(1^{\text {st }}-J u l\right)$ & 120 \\
South & $303\left(29^{\text {th }}-\right.$ Oct $)$ & $192\left(10^{\text {th }}-\right.$ Jul $)$ & 111 \\
\hline
\end{tabular}

\subsection{Climate Change Impacts on Seasonal Parameters Over Bale Highlands}

Climate change signal was appear over Bale Highlands [28]. As indicated in Table 6 each rainy season responded 
differently to RCP4.5 and RCP8.5 scenarios over Bale highlands. For instance, from near future (Near Century), intermediate future (Mid Century) and far future (End Century), the onset, cessation and LGP periods are likely to behaving differently. For Belg season, the onset date in RCP4.5 scenario is projected to be on April $4^{\text {th }}$, April $7^{\text {th }}$ and April $24^{\text {th }}$ for Near Century (2011 to 2040), Mid-Century (2041 to 2070) and End-Century, respectively.

Likewise, the onset dates of Kiremt under RCP4.5 scenario will be on July $19^{\text {th }}$, July $29^{\text {th }}$ and August $4^{\text {th }}$ for Near Century (2011 to 2040), Mid-Century (2041 to 2070) and EndCentury, respectively. On the other hand, Belg season onset date in RCP8.5 scenario will March $31^{\text {st }}$, April $6^{\text {th }}$ and April $20^{\text {th }}$ for near century (2011 to 2040), mid-century (2041 to 2070) and end-century, respectively. The onset dates of Kiremt season in the RCP8.5 scenario will July $20^{\text {th }}$, July $26^{\text {th }}$ and July $28^{\text {th }}$ for near century (2011 to 2040), mid-century (2041 to 2070) and end-century, respectively. The end date of Belg season under RCP4.5scenario will be May $27^{\text {th }}$, May $31^{\text {st }}$ and June $11^{\text {th }}$ for near century, mid-century and end century respectively. Likewise, cessation of Belg season in RCP8.5 scenario will be June $1^{\text {st }}$, June $6^{\text {th }}$ and June 12 th for near century, mid-century and end century, respectively. On the other hand the end date of Kiremt season inRCP4.5 will be November $2^{\text {nd }}$, November $6^{\text {th }}$ and November $8^{\text {th }}$ for near century, mid-century and end century, respectively. Similarly, the cessation of Kiremt season under RCP8.5 will be November $6^{\text {th }}$, November $9^{\text {th }}$ and November $6^{\text {th }}$ for near century, mid-century and end century, respectively over Bale Highlands (table 6). The Length of rowing period of Belg season in RCP4.5 will be 54 days, 54 days and 48 days for near century, mid-century and end century, respectively and under RCP8.5 will be 62 days, 61 days and 53 days for near century, mid-century and end century, respectively. For
Kiremt season the Length of rowing period in RCP4.5 will be 106 days, 99 days and 96 days for near century, mid-century and end century respectively and in RCP 8.5 will be 109 days, 106 days and 101 days for near century, mid-century and end century, respectively over the study area. The change of weather parameters like temperature and rainfall over Bale highlands will have both constructive and adverse consequences. The maximum temperature rises and the rainfall will enhance or reduced it affects social and economic activities over the study areas. [28]

The difference of onset, cessation and LGP from climatology of the study area showed in table 7. March $25^{\text {th }}$ was Belg onset climatology and it will shifts by 10,13 and 30 days for 2011-2040, 2041-2070 and 2071-2100 under RCP4.5 scenarios. Likewise, under RCP8.5 scenarios the season will shift by 6, 12 and 26 days 2011-2040, 2041-2070 and 2071-2100, respectively. End date of Belg season also shifts from June $17^{\text {th }}$ by $21,17,6$ days in RCP4.5 and 16, 11 , 35 days under RCP8.5 scenarios for 2011-2040, 2041-2070 and 2071-2100, respectively. Climatologically, July $8^{\text {th }}$ was Kiremt onset over Bale Highlands and it will shifts by 11,21 and 27 days for 2011-2040, 2041-2070 and 2071-2100 under RCP4.5 scenarios and also it will shift by 12,18 and 20 days 2011-2040, 2041-2070 and 2071-2100 under RCP8.5 scenarios, respectively. End date of Kiremt season shifts from October $26^{\text {th }}$ by 7,11 , and 13 days in RCP4.5 scenario and 11 , 14 and 11 days under RCP8.5 scenarios for 2011-2040, 20412070 and 2071-2100, respectively. LGP in Belg season was reduced by 30, 30 and 36 days for 2011-2040, 2041-2070 and 2071-2100 from climatology LGP (84 days) under RCP4.5 scenario and reduced by 22, 23 and 31 days in RCP8.5 scenario for the 2011-2040, 2041-2070 and 2071-2100, respectively (Table 7).

Table 5. Mean Seasonal Onset, Cessation and LGP of Base year (1986 to 2005).

\begin{tabular}{|c|c|c|c|c|c|c|}
\hline Seasons & Period & DoY & Onset & DoY & Cessation & LGP \\
\hline Belg & 1986-2005 & $85^{\text {th }}$ & Mar- $25^{\text {th }}$ & $169^{\text {th }}$ & June- $17^{\text {th }}$ & 84 \\
\hline Kirmet & $1986-2005$ & $190^{\text {th }}$ & Jul- $8^{\text {th }}$ & $300^{\text {th }}$ & Oct- $26^{\text {th }}$ & 91 \\
\hline
\end{tabular}

Table 6. Mean Onset, Cessation and LGP in RCP4.5 and RCP8.5 scenarios from 2011 to 2100.

\begin{tabular}{|c|c|c|c|c|c|c|c|}
\hline \multirow{2}{*}{ Seasons } & \multirow{2}{*}{ Period } & \multicolumn{3}{|l|}{ RCP4.5 } & \multicolumn{3}{|l|}{ RCP8.5 } \\
\hline & & SoS & EoS & LGP & SoS & EoS & LGP \\
\hline \multirow{3}{*}{ Belg } & $2011-2040$ & Apr-4 & May-27 & 54 days & Mar-31 & Jul-1 & 62 \\
\hline & $2041-2070$ & Apr-7 & May-31 & 54 days & Apr-6 & Jun-6 & 61 \\
\hline & $2071-2100$ & Apr-24 & Jun-11 & 48 days & Apr-20 & Jun-12 & 53 \\
\hline \multirow{3}{*}{ Kirmet } & 2011-2040 & Jul-19 & Nov-2 & 106 & Jul-20 & Nov-6 & 109 \\
\hline & $2041-2070$ & Jul-19 & Nov-6 & 99 & Jul-26 & Nov-9 & 106 \\
\hline & $2071-2100$ & Aug-4 & Nov-8 & 96 & Jul-28 & Nov-6 & 101 \\
\hline
\end{tabular}

Table 7. Shifting of Onset, Cessation and LGP between scenario's projection and base year.

\begin{tabular}{|c|c|c|c|c|c|c|c|}
\hline \multirow{2}{*}{ Seasons } & \multirow{2}{*}{ Period } & \multicolumn{3}{|l|}{ RCP4.5 } & \multicolumn{3}{|l|}{ RCP8.5 } \\
\hline & & SoS shit by & EoS shit by & $\Delta$ by LGP & SoS shit by & EoS shit by & $\Delta$ by LGP \\
\hline \multirow{3}{*}{ Belg } & $2011-2040$ & 10 days & 21 & 30 & 6 & 16 & 22 \\
\hline & $2041-2070$ & 13 days & 17 & 30 & 12 & 11 & 23 \\
\hline & $2071-2100$ & 30 days & 6 & 36 & 26 & 35 & 31 \\
\hline \multirow{3}{*}{ Kirmet } & $2011-2040$ & 11 days & 7 & 4 & 12 & 11 & 1 \\
\hline & 2041-2070 & 21 days & 11 & 11 & 18 & 14 & 4 \\
\hline & $2071-2100$ & 27 days & 13 & 14 & 20 & 11 & 9 \\
\hline
\end{tabular}




\section{Conclusion}

This study presents analysis of climate change impact on start date, end date and Length of growing period of Belg and Kiremt seasons over Bale highlands. The findings over Bale Highland is consistent shifting of start date, end date and Length of growing period of each seasons. Onset of Belg season shifts by 1 to 4 days, cessation of Belg season shifts by 1 to 6 days and the Belg LGP is reduced by 1 day to 8 days over Bale Highlands. Similarly, Kiremt season onset shifts by 1 to 6 days, cessation of kiremt season shifts by 1 to 9 days and the LGP of kiremt season reduced by 7 to 8 days in Northern and southern parts but increased by 4 days in the central parts and 7 days in the western parts of Bale Highlands. Over Bale Highland observed data, GCM date and farmer's perception showed similar result and shift of seasons over Bale highlands form 2 days to dekade. During the major growing season (Kiremt) there will be toward shifting of onset by 11, 21 and 28 days and 12, 18, 20 days in near (2011-2040), middle (2041-2070) and far (2071-2100) century under RCP 4.5 and RCP 8.5 scenarios, respectively. Cessation of Kiremt season under RCP 4.5 forward shifts by 7 to 13 days and RCP 8.5 scenarios forward shifts by 11 to 14 days from near to the end of 21 st century. Kiremt season length of growing period will reduced by 4 to 13 days under RCP 4.5 scenarios and 1 to 9 days under RCP 8.5 scenarios for near to the end of 21 st century from base years over Bale Highlands. For the period of the small rainy season (Belg), there will be toward shifting of onset by 10, 13 and 30 days and 6, 12, 26 days in near (2011-2040), middle (2041-2070) and far (2071-2100) century under RCP 4.5 and RCP 8.5 scenarios, respectively. Cessation of Belg season under RCP 4.5 forward shifts by 21 to 6 days and under RCP 8.5 scenarios forward shifts by 16 to 5 days from near to the end of 21 st century. Belg season length of growing period will reduced by 30 to 36 days under RCP 4.5 scenarios and 22 to 31 days under RCP 8.5 scenarios for near to the end of $21 \mathrm{st}$ century from base years over Bale Highlands. The onset of Belg at the end of century will shifts to May.

\section{Recommendation}

Change of rainfall pattern i.e. the emerging of Bega season with significant amount of rainfall is an early warning to design appropriate adaptation mechanism to prevent destruction of crops before and during harvesting. The past and the future rainfall distribution have difference that is also reflected as secondary impact on length of growing seasons. Thus, appropriate measure should be taken in the selection of crop types and crop varieties for the projected growing season. Information about the start of the rains is important for appropriate agricultural decision making so that reduction in yield of the crops is avoided by taking appropriate action. During those seasons, over Bale Highlands receives small and large rain lived. But, agriculturally small rainy and main rainy seasons are important over the study area. A delay or deficient Belg or Kiremt rainfall means absence of water and pasture, which may result in deaths of thousands of peoples and animals. Kiremt and Belg season rain is extremely important from agricultural economic point of view.

The coming future projection indicate that there is a decrease in LGP and the shift of onset and cessation of the seasons the concerned body would be assess the local community by aware creation them on the onset and cessation as well as Length of growing period. It is more likely to deviate from the traditional rain-fed agricultural practice (using Belg and Kiremt season only) to use Bega season as a growing season since the season is anticipated to come with significant amount of rainfall. Hence, appropriate cope up mechanisms and adaptation strategies towards unintended climate change should be re-framed in order to minimize risks that might emerge as declining of productivity of crops, shortage of water resources and physiological disruption due to extreme temperatures. This projection of LGP can assists to ease agroclimatic classification of the area. The output of this research also simplify for individuals researchers intended to develop crop calendar for the same area. The anticipated shift of the growing season to Kiremt maximum and emerging of Bega with significant amount of rainfall require appropriate acclimatization strategies to minimize risks, increase crop productivity, and avert food insecurity of the area.

\section{References}

[1] Environmental Protection Authority (EPA, 2014): Change Indicators in the United States, report from the www.epa.gov/climatechange/indicators Climate website.

[2] Chang H (2003); Basin hydrologic response to changes in climate and land use: the Conestoga River Basin, Pennsylvania. PhysGeogr 24: 222-247.

[3] Novotny EV, Stefan HG (2007) Stream flow in Minnesota: indicator of climate change. J Hydrol 334: 319-333.

[4] Kim U, Kaluarachchi JJ (2009) Climate change impacts on water resources in the Upper Blue Nile River Basin, Ethiopia. J Am Water ResourAssoc (JAWRA) 45 (6): 1361-1378.

[5] Abdo KS, Fiseha BM, Rientjes THM, Gieske ASM, Haile AT (2009) Assessment of climate change impacts on the hydrology of GilgelAbay catchment in Lake Tana basin. Ethiopia 23: 3661-3669.

[6] IPCC (Intergovernmental Panel on Climate Change, 2007). Summary for policy makers. Climate change 2007: the physical science basis, Working Group I contribution to IPCC fourth assessment report: climate change 2007. Geneva.

[7] Funk, C. et al. 2005. Recent drought tendencies in Ethiopia and Equatorial Subtropical Eastern Africa. FEWS-NET.

[8] Sayed, M. A. A., (2004): Impacts of climate change on the Nile Flow, Ain Shams University, Cairo, Egypt.

[9] Korecha, D. and Barnston, A. G. (2007). Predictability of June-September Rainfall in Ethiopia. Monthly weather review. V. 135 , p. $628-650$. 
[10] NMSA (National Meteorological Service Agency, 1996): Climatic \& Agro-climatic Resources of Ethiopia. Meteorological Research Report Series, 1: 1, January. Addis Ababa, Ethiopia.

[11] Bekele, F., 1997: Ethiopian use of ENSO information in its seasonal forecasts. Internet J. Afr. Studies, No. 2. Available online at http://www.ccb.ucar.edu/ijas/ijasno2/bekele.html.

[12] Korecha, D. and A. Sorteberg (2013), Construction of Homogeneous Rainfall Regimes for Ethiopia, Submitted to International Journal of Climatology.

[13] Miehe, S. and Miehe, G. (1994) Ericaceous Forests and Heath lands in the Bale Mountains of South Ethiopia: Ecology and Man's Impact. Siftung Walderhaltung in Afrika, Hamburg, $206 \mathrm{pp}$.

[14] Morton, B. (1976) A field guide to Ethiopian minerals, rock and fossils. Addis Ababa University Press, Addis Ababa.

[15] Messay Abebe, 2006. The Onset, Cessation and Dry Spells of the Small Rainy Season (Belg) of Ethiopia. National Meteorological Agency, Addis Ababa, Ethiopia.

[16] Segele, Z. T., and P. J. Lamb 2005: Characterization and variability of Kiremt rainy season over Ethioia. Meteor. Atmos. Phys., 89, 153-180.

[17] FARM Africa and SOS Sahel. (2007). Bale Eco-Region Sustainable Management Programme (BERSMP): Annual report.

[18] WBISPP (Woody Biomass Inventory and Strategic Planning Project, 1995): Socio-cultural and Economic aspects of crop, livestock and tree production. The Woody Biomass Inventory and Strategic Planning Project. Ministry of Mines and Energy. Ethiopian Energy studies and Research Center.

[19] Muleta D, Desalegn O. and Bikila Z. a (2015): Using NDVI for Prediction of Yield for Specific Crop Type: Case Study of Sinana District in Bale Zone.

[20] BZFEDO (Bale Zone Finance and Economic Development Office, 2010): Physical and socio Economic profile of Bale zone.

[21] WMO, 2009: Progress Report on the Implementation of the Global Observing System for Climate in Support of the UNFCCC 2004-2008. August 2009, GCOS-129 World Meteorological Station-TD/No. 1489, GOOS-173, GTOS-70.

[22] Australian Bureau of Meteorology, 2010. Rainfall variability in Australia. http://www.bom.gov.au/climate/data/index.shtml.Accessed.

[23] Stern, R., Rijks, D, Dale, I. and Knock, J. 2006. INSTAT Climatic $\quad$ Guide. $\quad 330 \quad$ pp. http://www.reading.ac.uk/ssc/software/instat/climatic.pdf/oct. 27/2010.

[24] Hoefsloot, p., 2009. LEAP (Livelihood Early Assessment Protection) version 2.1 for Ethiopia. By collaborative action of FAO, World Bank and World food programme. The Netherlands.

[25] Hare, F. K., 1983. Climate and Desertification. Revised analysis (WMO-UNDP) WCP-44 pp 5-20. Geneva, Switzerland.

[26] Thrusfield M (2007) Veterinary epidemiology (3rd edn). Blackwell Science, Ox-ford, UK. 2: 51-281.

[27] Legese W, Koricha D, Ture K (2018) Characteristics of Seasonal Rainfall and its Distribution Over Bale Highland, Southeastern Ethiopia. J Earth Sci Clim Change 9: 443.

[28] Legese W (2017) Climate Change Indication and Projection Over Bale Highlands, Southeastern Ethiopia. J Climatol Weather Forecasting 5: 212. 